\title{
Technology Retreats and the Politics of Social Media
}

\section{Adam Fish}

\author{
Lancaster University, Lancaster, United Kingdom, a.fish2@lancaster.ac.uk, \\ http://www.lancaster.ac.uk/sociology/about-us/people/adam-fish
}

\begin{abstract}
This essay examines weeklong technology retreats in Silicon Valley. These retreats embody digital healthism, which I define as the discourse that promotes the selfregulation of digital consumption for personal health. I argue that the self-regulation advanced by digital healthism insufficiently addresses the politics of media refusal. Technology retreats channel frustrations about social media use into opportunities for personal and corporate growth instead of political activism. I consider how technology retreats might participate in a dialogue about the regulation of social media platforms and companies by states. Evidence for these claims come from ethnographic research with the founders of a technology retreat in Silicon Valley.
\end{abstract}

Keywords: Regulation, Personalisation, Politicisation, Social Media, Governmentality, Healthism, Technology, Media Refusal, Technology Retreats

Acknowledgement: This article is dedicated to Levi Felix, co-founder of Camp Grounded, who passed away during the course of our friendship. Gratitude to Zev Felix, Brooke Dean, Ben Madden, Lyndsey Madden, and Joe Madden. Thanks to Theodora Sutton for major insights into Camp Grounded.

\section{Introduction}

In many communities in and around Silicon Valley, working on one's mental, physical, and even spiritual health is a marker of both personal and professional success (Ferenstein 2015). Google's “meditation leader”, Chade-Meng Tang, claims that meditation boosts emotional intelligence (EI), "And every company knows that if their people have EI, they're gonna make a shitload of money” (Shachtman 2013). In order to cultivate EI, Google offers meditation courses on campus that are attended by hundreds of employees (Kelly 2012). Google is not alone in providing meditation services for employees. Facebook's campus has a meditation room, and Twitter cofounder Evan Williams leads meditation retreats. It appears that in some Silicon Valley companies, spiritual practices and business success are seen to overlap. One recent manifestation of the ideal that personal and professional growth is intertwined is the phenomenon of technology retreats - multiday events framed by temporary non-use of networked technology.

Technology retreats exemplify the practice and discourse of digital healthism, or self-regulation of digital consumption for personal health. In this essay, I argue that the discourse of digital healthism involves a depoliticisation of social media, wherein perceived social media excess is addressed as an individual issue, as opposed to a corporate or state problem. Technology retreats, I argue, are a missed opportunity to collectively organise for structural or social regulation of social media platforms and corporations. Based on interviews and ethnographic experiences with the founders of 
a Silicon Valley technology retreat, this essay is equal parts critical analysis and polemic. It is an attempt to envision not only what is but what could emerge from a politicised culture of digital rejection.

Subjects abstaining from social media want to regain control, establish boundaries, resist information overload, and establish greater personal life balance (Woodstock 2011). Many limit use to particular sites and times (Kaun and Schwarzenegger 2014) or depart while retaining the possibility of returning (Brubaker et al. 2014; Light and Cassidy, 2014). These affective concerns could translate into "conspicuous nonconsumption", which refers to the ways in which the rejection of consumption becomes a public performance capable of accruing to the performer social capital (Portwood-Stacer 2013). "Conspicuous non-consumption" could be the ground for social solidarity. While affective experiences like technology retreats may coalesce into political activism (Papacharissi 2015), the "collective action frames" (Benford and Snow 2000) - ways of collaboratively identifying and addressing a problem - are not made explicit in the technology retreats. This, I argue, is a depoliticisation of the political potential of temporary media rejection.

My argument draws on qualitative research with the organisers of one Silicon Valley technology retreat, Camp Grounded, a service of the limited liability company Digital Detox ${ }^{\circledR}$. For this reason, this essay is not about the experience of being a participant in a technology retreat. Rather, it is about how institutions structure what is possible through rules, frames, and agenda setting. I am friends with the founders and councillors of Camp Grounded and have had many personal experiences and long discussions with them about life and society, as well as technology retreats and their inspirations. The key founder, the late Levi Felix, was a good friend who provided a wealth of insights into the origins, motivations, and practices of Digital Detox ${ }^{\circledR}$ and Camp Grounded. Despite this friendship, I remain critical and have challenged the founders with various versions of the critique I advance here. I am also indebted to the excellent fieldwork of Theodora Sutton (2014) who conducted ethnographic fieldwork at Camp Grounded. I include several quotes from her fieldwork in my analysis. In the following sections, I describe key aspects of Camp Grounded and use several political concepts to theorise the implications of Camp Grounded's avoidance of politics. My argument is that, instead of being potentially antagonistic to Silicon Valley, the temporary non-use of digital technologies represents the displacement of discord. Throughout the essay, I speculate on how technology retreats might participate in efforts to regulate social media platforms and companies.

\section{Case Study: Camp Grounded}

For four days each year, workers from Silicon Valley and elsewhere travel to Camp Grounded, a summer camp for adults along a river in the redwood forests of California. The retreat eschews digital technology and immerses participants in nature, community, creativity, self-analysis, and play. In 2014, the retreat was attended by employees from Silicon Valley companies such as Twitter, Facebook, Instagram, and Airbnb. In 2016, Google sent 200 workers to Camp Grounded. The employee who had the idea of bringing Google to Camp Grounded said: "There's sort of the standard off-site fun and bonding, you know, experience that everybody in the Bay Area offers to their teams and we really wanted to give them something different. And I was like OK, bear with us, it's summer camp. Let's take everyone away, there's no Internet whatsoever, and we're going to just see what happens and play" (Camp Grounded 2016). 
Felix and the other founders and councillors bring to Camp Grounded a specific vision of the ideal community based on interpersonal connection, a reverence for nature, and a celebration of direct experience. After an extended visit to a deserted island in Cambodia in 2009, they visited my wife and I where we were living on an intentional spiritual and eco-community in Southern California. Over handmade vegan sushi and a tea ceremony, two traditions they picked up in Southeast Asia, they told us about the idea for Camp Grounded. We continued to discuss the idea over the years and I began to research and they develop a culture of temporary media rejection inspired by the festival scene, most importantly Burning Man, of which we were both a part ${ }^{1}$.

These self-declared 'Burning Man hipsters' draw from the ethos of the participatory, radically self-reliant, and self-expressive festival ${ }^{2}$. The title of the camp they organised for Burning Man in 2015, "Zen as Fuck", gives a sense of the playful, parodic, and spiritual sensibility that they bring to Camp Grounded. The aesthetic of their camps and retreats is a mix of the 1960s and 2000s, the Merry Pranksters' psychedelic bus Further meets the nostalgic folksiness of a Wes Anderson movie. At Camp Grounded, the freedoms associated with this countercultural orientation are constrained by several rules.

The rules of Camp Grounded are simple and include prohibitions against technology, watches, ageism, wearable technology, drugs or alcohol, children, and glow sticks/glitter/blinking lights. The most important rule is no ' $\mathrm{W}$ ' (work) talk. Participants are asked to take on a playful pseudonym. Events include live music, kayaking, playshops (play/workshops), sailing, campfires, arts, dancing, talent shows, singing, climbing, typewriters, capture the flag, stargazing, etc. The events at Camp Grounded are designed to be open-ended, and participation is voluntary. Various practices are appropriated from Eastern and New Age spiritual pursuits, such as yoga, meditation, silent eating, the anthropomorphising of nature, the wearing of white, and the symbolic burning of paper on which past transgressions are written. The rules, pseudonyms, and events are designed to occlude the outside world of work, family, and digital technology. As testified in numerous newspaper articles and across their website, participants are having transformative experiences at Camp Grounded, which has now been franchised to several additional regions in the United States.

One issue not included as one of the 30-plus playshops is the politics of social media. Talking politics is not ' $W$ ' talk, so it is not prohibited, but it is a serious realworld issue that might be ignored amongst the more immersive and fun experiences to be had. It is likely that some participants violate the rules and engage in work and other 'real world' talk. Quietly, some may provide their real names, educational pedigree, and corporate affiliation. Regardless of the existence of these renegades willing to violate the protocols, my friends at Camp Grounded tell me that sustained and public deliberation about the politics of "media refusal" does not happen (PortwoodStacer 2012). Camp Grounded is simply too festive.

Without deliberating on the politics of social media it is impossible to articulate a critique of social media. Without critique, it is difficult to organise to influence the regulation of social media platforms and social media companies. Without organisa-

\footnotetext{
${ }^{1}$ A modest budget for Burning Man is $\$ 1600$, so at $\$ 745$ - which includes food and lodging a ticket to Camp Grounded is relatively affordable. Scholarships and low-income tickets are available.

${ }^{2}$ Thank you to Lyndsey Madden for this term.
} 
tion, efforts to critique social media remain at the individual instead of the collective level.

While it is pitched as a digital detox, digital technologies form a consistent backdrop for the events. At Camp Grounded there are several wooden stands: an 'inbox' to leave paper notes and tangible gifts, a 'human search engine' where participants write down a question and come back later to potentially find it answered, and 'clip art' where participants clip polaroids and drawings to strings. Instead of digital laptops, there are analogue typewriters. Instead of watches, time is described in human terms: for instance, as Felix often said, 'about the time it takes to boil an egg'. Upon arrival, participants are directed to the 'tech check' where two people in white overalls move a hula-hoop up and down participants like scanners checking for technology (Sutton 2014, 27, 31). Thus, while digital technologies are absent in form, they are present in symbols. Against these symbols of digital technology, the organisers create an immersive space of catharsis and irony. I argue that these performances fetishise technology, transforming technology into a symbol whose semiotic power is reinforced through its temporary rejection. This fetishisation elevates technology to a state beyond political critique and ritually naturalises the use - and potential overuse - of technology.

Participants connect Camp Grounded to the history of Californian counterculture. A person calling themselves Submarine explained: “[The retreat] isn't happening here because it's the tech centre. It's happening here because this is the place that created Burning Man and which brought mindfulness into the Western World. It's a centre of self-absorption and self-reflection. It starts being a good thing, but the individual here is rampant" (Sutton 2014, 9). Another participant, Monopoly, agreed: "In San Francisco, you have the technology and the wellness community. Berkeley and Oakland has the hippy culture. Wellness retreats have been around for a long time. So that - plus tech-orientated people - results in a wellness retreat for techies" (Ibid.). While it may provide a space for wellness, Camp Grounded is adamant about its not being a space for professional networking.

Camp Grounded is serious about prohibiting ' $\mathrm{W}$ ' talk, warning any would-be networkers: "This will not be a meet-up opportunity to make contacts that further your career. There will be no cocktail hour or reception for anyone to explain what they do, play the 'we know the same people' game, or try and figure out how they can launch a company together...” (Camp Grounded 2017a). I argue that while there is an effort made to frame Camp Grounded as an alternative to work, Camp Grounded does have a generative relationship with many companies in Silicon Valley.

For example, Camp Grounded is collaborating with The Go Game, a San Francisco company specialising in corporate retreats, to offer scavenger hunts, road trip games, and other major private events. The Go Game's tagline is "Play like it's your job”, and they have worked with Silicon Valley companies such as Facebook, Netflix, Salesforce, Adobe, Yahoo!, Google, and Hewlett Packard (The Go Game 2016). The Go Game invites these companies to participate: "Bring us your over-competitive salesperson, your skeptical product manager, and stressed out director. The Go Game will braid you all into a friendship bracelet of professional effectiveness that will be the envy of your professional peers." In addition to collaboration with corporate partners such as The Go Game, Camp Grounded also offers "Recess", short experiences on corporate campuses where they promise to "infuse some play into your company culture” (Camp Grounded 2017b).

Taylor Tobin, an administrative business partner at Google, celebrated Camp Grounded's positive impact on corporate culture. She said that the 200 Google em- 
ployees returned "refreshed and reconnected" and more committed to their workbased "connections" (Ibid.). Camp Grounded is devoted to helping corporate "leadership create and maintain an integrated culture of balance, play and Digital Detox so the program doesn't end when we say goodbye" (Ibid.). In this way, the benefits of a corporate retreat continue into the office. I would argue that Camp Grounded is not, as it claims, a "true vacation from [your] j-o-b". Rather, it complements work by providing to workers an opportunity to develop "personal freedom, creative thinking, [and] liberation from technology" (Ibid.). These experiences may make the Silicon Valley worker feel "refreshed" by providing to them a new outlook on the relationship between digital culture and personal health. Furthermore, technology retreats enable frustrations about work to be channelled into creative activity and personal growth.

Some of these ideas have a historical legacy in California. Technology retreats are a distinct iteration of Silicon Valley's fetishisation of technology and celebration of self-regulation (Turner 2006). Writing about the 1960s counterculture, Lasch states that "people have convinced themselves that what matters is psychic selfimprovement - getting in touch with their feelings, eating health food", and that this becomes wrapped in the rhetoric of authenticity (1979, 4-5). In Silicon Valley, technologies take on an almost cult-like status as tools capable of remarkable selfempowerment through creating the means for both financial independence and personal discovery. Camp Grounded and Silicon Valley are linked through a complementary relationship to technology. While one embraces and another temporarily rejects digital technology, both have made a business and a culture out of fetishising technology. Together, Silicon Valley and Camp Grounded create opportunities for self-empowerment through the embrace or the temporary rejection of technology.

Contemporary technology retreats modernise the values of the 1960s counterculture and synthesise two additional contemporary cultures: the post-dotcom technology industry, and the eco-spiritualism of the 2000s, forming a distinct West Coast culture called the "New Edge" (contra the "New Age" [Zandbergen 2012]). For the New Edge, hippy spirituality and yuppie corporate culture merge around an emphasis on individual acquisitions of 'wellness', both spiritually personal and materially pleasing. This is an example of "peer progressivism" (Johnson 2012) that champions decentralisation, collective wisdom, amateurs, "virtuous" peer-to-peer sharing (Benkler and Nissenbaum 2006), and “organizing without organizations" (Shirky 2008). Camp Grounded merges New Edge peer-progressivism with eco-spiritual practices such as sunrise celebrations, silent dinners, ascetic rites such as fasts, and ecstatic dance. These are manifestations of the "Californian Ideology" (Barbrook and Cameron 1996), a promise that a more spiritual individual can be made through the consumption of transformative experiences, intense relationships with technology, and close encounters with each other and nature.

A key metaphor for Camp Grounded positions the healthy consumption of media as food ${ }^{3}$. Speaking in one of my graduate student seminars, Felix compared dietary fasts to media refusals. His logic follows that gluttony, in media or food, is bad. On the one hand, frivolous social media are like genetically modified organisms, of limited health value. On the other hand, organic food is like an educational documentary that provides sustenance. From the outset, the term used - and copyrighted - by Camp Grounded, 'Digital Detox ${ }^{\circledR}$,' suggests the same frame of reference as food detoxes. Detoxing with food aims to remove what is considered 'toxic' from a diet. As Alexis Madrigal (2013, n.p.) writes, the name “conjures up the same chemophobia

\footnotetext{
${ }^{3}$ Thank you to Theodora Sutton for this insight.
} 
that pervades the current whole foods movement. It says technology is toxic and addictive, unnatural". Camp Grounded's roots in Western attitudes towards what is "natural" informs the search for a more "balanced" relationship to digital technologies.

Camp Grounded is a space where heavy digital users re-program their relationship to personal technology. Striving for authenticity and meaning, they romanticise the natural and forgo technology in an effort to reassert how they will use technology in the future. However, participants are not looking to drastically change their lifestyles or the world around them. A participant, Smitten, explained: "I wouldn't want to live without [technology], but I just want to be more balanced” (Sutton 2014, 38). After the technology retreat, those who work in Silicon Valley frequently report returning to their desks invigorated. Any epiphany into the nature of technological use - and its ubiquity - benefits employers, as the revivified workers may provide insights into technological use, misuse, and rejection. In this manner, what might be oppositional to the fiscal bottom line - users stop using social media - is depoliticised and transformed into a corporate asset.

Technology retreats pay careful attention to context (nature), embodiment (play), and consumption (technology and food) in order to teach 'healthy' self-regulation - a necessary skill for a digital worker interpolated by capitalism. Digital healthism is a discourse of self-regulating digital consumption for personal health. The goal of the technology retreat is to improve one's health so that one may live or work better. The promise of a better life, however, does not include advocating for the structural regulation of social media platforms and companies. This reality is unfortunate because emotions and self-care are important political motivators (Papacharissi 2015).

The organisers of Camp Grounded are not Luddites. They use the Internet and readily admit that they are reliant on it in many ways. Camp Grounded advertises and sells all its tickets online, and organisers use social media for promotion. One founder can quite often be seen tapping away at his phone in social settings. Nevertheless, the organisers claim that the present era of ubiquitous social media brings people out of equilibrium with nature and community. To help them when they leave, participants are given a small pamphlet, entitled "A Guide to Bringing Balance Back to Your Everyday Life”, which provides exercises for those wanting to continue their digital detox during the work week. Some of the recommended exercises to "find balance" include "liking" someone in person, device-free meals, napping, buying an alarm clock so as to avoid the use of a phone for alarms, and avoiding 'shexting' using the bathroom while texting. Challenged by complexity theorists as reductive (Urry 2002) - but sought by individuals - equilibrium is the balance achieved despite the presence of competing forces. A feeling of balance results from a life of agency, meaning, and "ontological security" - the awareness of personal and historical continuity - all of which require capital (Giddens 1991). A founder of Camp Grounded claims that time spent on social media is time not spent on analogue creativity, inperson connection, traditional arts, and oceanic experiences within nature. These claims of Camp Grounded do not align with insights from some media studies scholarship that suggest that networked connectivity often results in meaningful and diverse social experiences (Papacharissi 2010). Nevertheless, 'balance' is a term that consistently reemerges, in reference to that which individuals strive towards through the practice of social media abstinence. While individual balance is emphasised, collective politics is not. This I argue is a depoliticisation of social media. In the next section, I argue that this happens because temporary social media rejection is positioned as an issue of personal instead of social regulation. 


\section{Governmentality and Digital Health}

Several scholars draw from the later Foucault seminars (1994 [1977-1984]) when examining the relationships between institutions, subjectivity, and technology (Marwick 2013; Portwood-Stacer 2012, 2013; Rose 1998). Foucault's theory of governmentality explores how institutions produce willing subjects through empowering their personal expertise. Governmentality is often used to theorise the shift of regulation in the 1980s, in the United States and the United Kingdom, from the regulation of the state to the self-regulation of the individual.

Theories of governmentality have been deployed previously to investigate media refusal. Portwood-Stacer uses the theory to define "social media refusal [as] an ascetic practice of self-care" (2012, n.p.). She writes that "social media fasts involved depriving the self of a desired object in the interest of purifying the self and heightening one's consciousness" (Ibid.). Marwick (2013) examines how Silicon Valley workers edit, monitor, and conform themselves to commercial ideals. Marwick's (2013) research shows how the social media platforms made in Silicon Valley personify selfentrepreneurialism. Like Burning Man, regularly frequented by the Silicon Valley workers and the founders of Camp Grounded, technology retreats have emerged as another "socio-technical commons" (Turner 2009) that influences the planning of social media platforms. Technology retreats depoliticise social media by framing technology non-use in terms of individual choice instead of an opportunity to mobilise in order to regulate social media platforms and companies. While participants are free to consider political solutions to what they perceive as social media overuse, Camp Grounded does not provide a collective action frame for the direction of this political agitation. Media refusal is something individuals do in order to improve personal health, and not to change the world for the better.

Rose's concept of "healthism" defines health as that which is good for the individual $(1998,243)$. As the proliferation of meditation centres and yoga studios in Silicon Valley and other wealthy Western cities attest, working on one's spiritual self is intertwined with personal health and professional success. Healthism transforms the ideas of success and failure as being "construed in the vocabulary of happiness, wealth, style and fulfillment” (Ibid.). Technology retreats frame temporary media refusal as an issue of personal health. Thus, the discourse of digital healthism claims that a more "balanced" relationship with technologies should emerge not from the influence of federal regulation but from within the individual.

Technology retreats are, in part, a reaction to the burdens of digital work and the over-abundance of digital sociality. In this way, digital retreats and digital labour are mutually constitutive. Technology retreats temporarily reject the consumption of technology by the digital workers who produce it for mass consumption. This is not paradoxical. Technology retreats are not the escapes from work they claim to be. On the contrary, they constitute the leisure and off-work practices that make digital work endurable. By valorising the opposite of digital labour - non-digital play - technology retreats provide a temporary moment of recalibration for workers.

On the personal level, technology retreats fuel Silicon Valley, as workers may return to work with added inspiration, productivity, and insights into the evolving relationship with technologies. On the discursive level, technology retreats may co-opt through incorporating resistance to social media. On the social level, retreats are playful opportunities to have collaborative fun in nature, but this communitas does not translate into a political movement for federal or corporate regulation. 
Working in the digital industries today means working for companies that value personal agency, creativity, and passion (Marwick 2013; Neff 2012; Ross 2003). This is not just sophisticated branding on the part of human resource departments. Workers who have profound or joyful experiences outside of work are valuable to companies in the creative industries. Corporations and governments celebrate the happiness indicators of its workers and citizens and in the process create a bustling market for well-being (Davies 2015). The employees who work on themselves at technology retreats help technology companies because these workers are refreshed, see technology in a new light, and are self-reflexive - but not so reflexive as to challenge or organise against the status quo. Technology retreats enable the safe exorcism of dissent so that technocentric hegemony may continue through the embodied work of its labourers.

The participants in media retreats have problematised the role of technologies in their everyday lives. They come to the redwood forests of California somewhat disillusioned by the promise that new technologies and new working environments make digital labour less alienating. Through networked productivity, labour was supposed to be more humane, participatory, liberating, democratic, and inclusive. Once repressed or exploited in the Fordist era, worker creativity was to be unlocked and workers would no longer be alienated from the digital products they produced (Terranova 2000). This is the Internet version of the "new spirit of capitalism" which coopts the "artistic critique" that capitalism has become less alienating (Boltanski and Chiapello 2005; Fisher 2010). Seen as an example of a digital discourse, technology retreats legitimise capitalism through an incorporation of this critique. In providing 'transformative' experiences, technology retreats re-inspire and re-tool the digital worker, renewing skills of self-regulation and self-entrepreneurialism, while depoliticising any latent critique of their industry.

Media retreats are one small example of how technology industries manage and learn from conflict, while at the same time caring for and educating workers. Individual risk-taking is celebrated in a culture that valorises “disruption" (Neff 2012), but so is its inverse, socially-executed stability through self-care, which is good for digital workers, digital industries, and capitalism itself. Digital healthism is a discourse of self-regulation that brings together personal well-being, technological moderation, and professional success. Media retreats depoliticise social media through framing technology rejection as an issue of playful and spiritual self-regulation instead of the social regulation of technology corporations. The section that follows examines how social media is politicised by states and corporations.

\section{Politicising Social Media Refusal}

The efforts of Camp Grounded are just one example of how social formations are developing to curb perceived social media overuse. The efforts of the French government and some German automobile companies, described below, show a different approach to media refusal that stresses not the bottom-up self-regulation of Camp Grounded but instead top-down structural regulation. In August 2016, the French government passed the controversial El Khomri law, a policy that would enable employers to negotiate more flexible extensions in the much-celebrated 35-hour workweek. To offset this potential for extended hours, Article 25 of the El Khomri law, “The Adaptation of Work Rights to the Digital Era”, enshrines the "right to disconnect" 
from work email after work hours ${ }^{4}$. Likewise, Daimler, a German automobile manufacturer, encourages workers to delete work emails during vacation, and Volkswagen, another German company, limits after-work communication by shutting down its company computers (BBC 2014). Few, if any, American companies have installed protocols to limit after-work communication. On the contrary, apps and platforms are designed and used to increase after-work productivity (Gregg 2011). According to a recent poll, between 52 and 70 percent of American workers regularly check work email during off work hours (60 Minutes/Vanity Fair 2015). While France and Germany have politicised the relationship between social media and work, Americans appear to have embraced the blurring of the distinction between social media and work.

France's "The Adaptation of Work Rights to the Digital Era" is an example of the politicisation of technology, namely, email (Mackenzie and Wajcman 1985; Winner 1980). By politicisation, I refer to the process by which things, practices, and concepts become political ${ }^{5}$. The law is an illustration of how limits can be imposed by governments. Conversely, technology retreats see the perceived overuse of communication technologies as an issue to be addressed by the individual, not government. The result is the neglect of the political potential of the emotions generated during the technology retreats. The political possibility of media retreats might be found through emphasising not only personal regulation of social media use but also structural regulation of social media platforms and companies in the manner made into law by the French.

"The Adaptation of Work Rights to the Digital Era" is a social regulation that checks corporations not individuals. The law is an example of what architectural critic Lewis Mumford (1930) argued for - a return to organic humanism. He used the term in a general sense to encourage architects and city planners to create buildings and cities that structure movement through "checks and restrictions" as well as creating opportunities for “quiet states of beatitude” (Ibid., 350). Today's designers of social spaces - Silicon Valley platform engineers and the organisers of immersive events such as technology retreats - could be influenced by the efforts of the Germans, French, and Mumford's insights into how to create systems of social regulation wherein individuals might have beatific social media experiences, while also developing a political commitment to regulatory "checks and restrictions."

\footnotetext{
${ }^{4}$ The proposed French law reads, "The development of information and communication technologies, if badly managed or regulated, can have an impact on the health of workers.... Among them, the burden of work and the informational overburden, [and] the blurring of the borders between private life and professional life..." (Collins 2016).

${ }^{5}$ There are many theories of political force - from Marx's theory of capital's exploitation of labour to Weber's iron cage of bureaucracy and Deleuze's control society. Because regulation is key to the exercise of both the state and the self in the state I select a state-centric theory of political power. Thus, while social media can be politicised, it can also be depoliticised. If politicisation extends the reach of the state, depoliticisation "rolls these frontiers back" (Jessop 2014, 213). Depoliticisation may include forms of subjectivity that are dependent upon "contingent rewards for behavior," that "may turn potential sources of resistance or obstruction into self-responsibilised agents of their own subordination” (Ibid., 216-217), and that "thematise some issues as inappropriate for political policy making" (Ibid., 223). The forms of depoliticisation may be challenged by "repoliticisation," which "reintegrates depoliticised spheres into the political” (Ibid.).
} 
I argue that technology retreats depoliticise social media by placing the responsibility of limiting Internet use on the individual, and rewarding limited use with hedonistic and spiritual experiences. My concern is that this softens the political potential of media resistance with leisure and recreation. Politics is not part of the agenda at Camp Grounded, and efforts are made to omit ' $W$ ' talk which I would argue may not only refer to 'work' but also outside 'world' talk. Emphasis is on fun and personal discovery, not government and civil society.

Speaking about media refusal in terms of individual actions sidelines the role of governments and civil society in regulating social media platforms and companies. The social regulation of Internet use in the model of either France or Germany is not an option discussed at Silicon Valley technology retreats. This is surprising, considering the range of playshops offered during the retreat, and Felix's sophisticated opinion about the problems associated with what he sees as an overuse of digital technologies - testimony provided in numerous talks around the world, including several in my classes at Lancaster University in 2015. By offering no "collective action frame" (Benford 2000) for the creation of political organisation, a political orientation remains unencouraged by Camp Grounded organisers and councillors. After the retreat, participants are free to do as they wish. None that I know have organised to pressure for the regulation of digital technologies. While they are at Camp Grounded, participants are not challenged to consider the politics of social media. I would argue that ignoring the politics of social media in this context is a depoliticisation of social media. Participants come to Camp Grounded because they agree that there is a problem with the overuse of digital technologies. But instead of addressing this as a structural problem, correctable through activism and regulation, they are encouraged to frame it as a personal problem.

On the contrary, Camp Grounded is focused on individualised self-development and self-responsibility. This stress placed on individual choice is also emphasised in Silicon Valley's technologies and is discussed in terms of 'personalisation', or algorithmically selected recommendations. In exchange for personal data, sold in bulk to advertising companies, users of social media platforms get free social network features such as personalisation. While it can facilitate online shopping, personalisation can also result in "filter bubbles" (Pariser 2011) wherein users are predominantly exposed to content of a similar political persuasion. This may have a negative impact on the diversity of opinions aired in the networked public sphere (Hindman 2009). With personalisation, social media becomes a mirrored world reflecting one's own subjectivity. The centring of experience on the individual happening online is also happening in political activism.

Bennett (2012) writes about the fragmentation or individualisation of politics, what he calls "personalized politics," wherein the individual replaces collective action frames. This individualism is the result of larger historical processes in the later half of the twentieth century that include marketisation, globalisation, privatisation, financialisation, and other signatures of neoliberal economics. As Reestorff (2014) shows in her analysis of Femen, the topless feminist protest movement, the circulation of affect is key to this era of personalised politics. But by omitting to connect the critical psychology of social media to a critical sociology of social media, technology retreats do not provide the space for affect to develop into personalised politics. 


\section{Conclusion: The Moral Power of Technology Retreats}

In the past, when technology was rejected by student activists in the San Francisco Bay Area, it was done so as to make a political point. In the late 1960s, Free Speech activists at the University of California, Berkeley, protested against the computerreadable punch cards because they rendered "the embodied lives of individual students as bits of computer-processed information” (Turner 2006, 14). For many in the Free Speech Movement, "computers loomed as technologies of dehumanization, of centralized bureaucracy and the rationalization of social life" (Ibid., 2). At the same time, fifty miles south of Berkeley at Stanford University, an obsession with technology led down a different path. Douglas Engelbart, a participant in the counterculture and inventor of the personal computing windows interface, believed that computers "offered men and women the chance to enter a world of authentic identity and communal collaboration" (Ibid., 14). Today, the technology retreats of Silicon Valley are situated geographically and philosophically at the convergence of spiritual selfregulation, environmental consciousness, and technological utopianism. But today's culture of technological rejection does not have the political resonance it had for Free Speech activists. It is more like a form of lifestyle consumerism, seeking not social regulation but personal regulation and balance (Portwood-Stacer 2013).

In line with New Age spirituality more generally, Camp Grounded believes in positive reinforcement (Foot 2014). It implicitly draws from the spiritual traditions of abstinence and asceticism, to assist people in turning away from an over-reliance on social media and towards practices they see as life-enhancing, such as human contact, community interaction, work/play balance, and artistic expression. The embrace of nature and individualism while negating technology and collective politics is problematic for any effort seeking to create social equilibrium. A less contradictory assemblage of concepts and practices designed to address a perceived over-use of social media would bring together both the personal regulation and the social regulation. Social media abstinence appears to be a lifestyle choice surrounding individual consumption, and not an intervention on the collective political level. Lifestyle choices (like social media self-regulation) may translate into lifestyle politics (social media rejection) and even more radical lifestyle activism (grassroots movements for the regulation of Silicon Valley companies) (Portwood-Stacer 2013). But as yet, the personal regulations advocated by technology retreats have not developed into collective political action.

The emergence of a social movement for the organic humanistic regulation of social media could emerge first on the individual level, and with events like Camp Grounded. Individuals are beginning to recognise the politics of social media abstinence not just on the personal but also the collective level. Consider how in response to Facebook's “massive-scale emotional” manipulation of almost 70,000 users by testing whether exposure to disturbing content created less than jovial Facebook posts (Kramer et al. 2013), which many deemed unethical (Blue 2014), the social movement called 99 Days of Freedom helped users abstain from social media for over three months. Over 40,000 people participated in this form of collective social media abstinence. Some, more drastically, committed a form of 'die-in', an 'infocide' assisted by software such as the "Web 2.0 Suicide Machine", which automatically deletes every social media account of a user. While "massive-scale emotional" manipulation irritates some, to others this irritation has translated into political activism. The role played by the grassroots in these cases is not known, but France's El Khomri 
law and the efforts of German automobile manufacturers show how top-down regulations can limit digital overload.

I can imagine a social movement designed to put pressure on Silicon Valley companies to address the issue of social media overuse. Camp Grounded could contribute to these efforts by including a session at the end of the retreat that was focused on organising activism towards this goal. It would not be surprising if this movement began in the San Francisco Bay area, where backlash has fomented against Silicon Valley as an elitist force for gentrification. As a form of protest, as well as a way of creating a more intimate consumer experience, some local shops, cafes, churches, synagogues, and clubs have a no-phone-use policy. For example, Awaken Café and Analog Bar, both in Oakland, forbid the use of phones and laptops for several days a week. As CNN reported, a number of establishments in San Francisco forbid patrons from wearing the now-defunct Google Glass (Gross 2014). In this way, urban space has changed to accommodate, and in some instances rebuff, the always-on or "evertime” networked society (Morrison and Gomez 2014).

However, while individual proprietors may reject technology use by patrons, these concerns have not yet fomented into a political movement. A more politicallyengaged future is possible, as social media refusal could manifest into "politicised asceticism" (Karpi 2011) that may interface with work as well as faith-based practices. In 2012, Facebook overtook chocolate, swearing, and alcohol as the most tweeted thing given up for Catholic Lent (Schoenebeck 2014, 1). Jewish artists created a Sabbath Manifesto whose first principle is to avoid technology. Is there a moral power behind media abstinence capable of fomenting into a social movement able to pressure social media companies to make their platforms less addictive?

Political philosopher John Rawls' concept of moral power includes “a capacity for a sense of justice and for a conception of the good" $(1996,19)$. By good, he means what is valuable; by justice, he refers to what is fair. Individuals best achieve personal balance with "ontological security" (Giddens 1991) and living within systems that value fair and just moral power. Governments, corporations, and other social agents need to be motivated by moral powers if they are going to value a just and fair society and contribute to an Internet that embraces organic humanism.

A moral power in technology retreats can be imagined that goes beyond selfregulation to social regulation. Through reflexive exercises at media retreats, social media abstinence may establish a blueprint for a democratic approach to the problems associated with a heavily self-mediated society. Valuing the moral power of social media could result in regulatory efforts to foreground the Internet as an inclusive public sphere, challenge the filter bubble phenomenon, and oppose its transformation into a platform for the commodification of attention.

Social networks, instead of atomised individuals, constitute the Internet. Social media rejection deserves a social movement that reflects this connectivity.

\section{References}

60 Minutes and Vanity Fair. 2015. How do Americans Really Feel About Vacation days? Vanity Fair. Accessed June 20. http://www.vanityfair.com/news/2015/07/60-minutes-pollvacation-days

Barbrook, Richard, and A. Cameron. 1996. The Californian Ideology. Science as Culture, 6(1): 44-72.

BBC. 2014. Should holiday email be deleted? BBC News. Accessed June 20. http://www.bbc.co.uk/news/magazine-28786117 
Benford, Robert, and David Snow. 2000. Framing Processes and Social Movements: An Overview and Assessment. Annual Review of Sociology 26: 611-639.

Benkler, Yochai, and Helen Nissenbaum. 2006. Commons-based Peer Production and Virtue. Journal of Political Philosophy 14(4): 394-419.

Bennett, W. Lance. 2012. The Personalization of Politics: Political Identity, Social Media, and Changing Patterns of Participation. The Annals of the American Academy of Political and Social Science 644: 20-38.

Boltanski, Luc, and Eve Chiapello. 2005. The New Spirit of Capitalism. International Journal of Politics, Culture and Society 18: 161.

Blue, Violet. 2014. Facebook: Unethical, Untrustworthy, and now downright harmful. ZDNet. Accessed July 19. http://www.zdnet.com/article/facebook-unethical-untrustworthy-andnow-downright-harmful/

Brubaker, Jed. R., Mike Ananny, and Kate Crawford. 2014. Departing Glances: A Sociotechnical account of 'Leaving' Grindr. New Media and Society 18(3): 373-390.

Camp Grounded. 2016. Google Camp. YouTube. Accessed March 17. https://www.youtube.com/watch?v=8idsyQ5s4b4

Camp Grounded. 2017a. About. Accessed March 17. http://campgrounded.org/about/

Camp Grounded. 2017b. Corporate Offerings. Accessed March 17. http://digitaldetox.org/corporate-2/

Collins, Lauren. 2016. The French Counterstrike Against Work E-Mail. The New Yorker. Accessed June 20. http://www.newyorker.com/culture/cultural-comment/the-frenchcounterstrike-against-work-e-mail

Davis, William. 2015. The Happiness Industry: How the Government and Big Business Sold Us Well-Being. London: Verso.

Ferenstein, Gregory. 2015. The Age of Optimism. Medium. Accessed March 17. https://medium.com/the-ferenstein-wire/silicon-valley-s-political-endgame-summarized$1 \mathrm{f} 395785 \mathrm{f3c1}$

Fisher, Eran. 2010. Contemporary Technology Discourse and the Legitimation of Capitalism. European Journal of Social Theory 13(2): 229-52.

Foot, Kirsten. 2014. The Online Emergence of Pushback on Social Media in the United States: A Historical Discourse Analysis. International Journal of Communication 8: 1,313$1,342$.

Foucault, Michel. 1994. Technologies of the Self in Ethics: Subjectivity and Truth. New York: The New Press.

Giddens, Anthony. 1991. Modernity and Self-Identity: Self and Society in Late Modern Age. Cambridge: Cambridge University Press.

Gregg, Melissa. 2011. Work’s Intimacy. London: Polity Press.

Gross, Doug. 2014. Google Glass targeted as symbol by Anti-Tech Crowd. CNN. Accessed August 7. http://www.cnn.com/2014/04/14/tech/mobile/google-glass-attack/

Hindman, Matthew. 2009. The Myth of the Digital Divide. Princeton: Princeton University Press.

Jessop, Robert. 2014. Repoliticising depoliticisation: theoretical preliminaries on some responses to the American fiscal and Eurozone debt crises. Policy \& Politics 42(2): 207-223.

Johnson, Steven. 2012. Future Perfect: The Case for Progress in a Networked Age. New York: Allen Lane.

Karpi, Tero. 2011. "Digital Suicide and the Biopolitics of Leaving Facebook." Transformations 20, Accessed November 14. http://www.transformationsjournal.org/journal/issue_20/article_02.shtml

Kaun, Anne, and Christian Schwarzenegger. 2014. 'No social media, less life?' Online Disconnection in Social Mediatized Worlds. First Monday 19(11): 5497.

Kelly, Caitlin. 2012. OK, Google, Take a Deep Breath. New York Times. Accessed November 14. https://veranurahma.wordpress.com/2017/12/06/cara-tambahkan-latar-belakanggmail/ 
Kramer, Adam, Jamie Guillory, and Jeffrey Hancock. 2013. Experimental Evidence of Massive-Scale Emotional Contagion Through Social Networks. Proceeds of the National Academy of Sciences of the United States of America, 111(24): 8788-8790.

Lasch, Christopher. 1979. Culture of Narcissism: American Life in an Age of Diminishing Expectations. New York: Warner Books.

Light, Ben, and Elija Cassidy. 2014. Strategies for the Suspension and Prevention of Connection: Rendering Disconnection as Socioeconomic Lubricant with Facebook. New Media and Society 16(7): 1169-1184.

MacKenzie, Donald, and Judy Wajcman. 1985. The Social Shaping of Technology. Buckingham: Open University Press.

Madrigal, Alexis. 2013. 'Camp Grounded,' 'Digital Detox,' and the Age of Techno-Anxiety. The Atlantic. Accessed June 20. http://www.oktrik.com/2017/12/apakah-ada-cara-atautrik-untuk.html

Marwick, Alice. 2013. Status Update: Celebrity, Publicity, and Branding in the Social Media Age. New Haven: Yale University Press.

Morrison, Stacey, and Ricardo Gomez. 2014. Pushback: Expressions of Resistance to the "Evertime of Constant Online Connectivity." First Monday 19(8).

Mumford, Lewis. 1930. The Critique of Humanism. New York: Brewer and Warren.

Neff, Gina. 2012. Venture Labor: Work and the Burden of Risk in Innovative Industries. Cambridge: MIT Press.

Papacharissi, Zizi. 2010. The Private Sphere. London: Polity Press.

Papacharissi, Zizi. 2015. Affective Publics: Sentiment, Technology, and Politics. Oxford: Oxford University Press.

Pariser, Eli. 2011. Filter Bubble: What the Internet Is Hiding from You. New York: Penguin Press.

Portwood-Stacer, Laura. 2012. How We Talk About Social Media Refusal Part 2: Asceticism.” FlowTV. Accessed November 14. http://flowtv.org/2012/09/social mediaabstinencee-part-2-asceticism/

Portwood-Stacer, Laura. 2013. Social Media Refusal and Conspicuous Non-Consumption: The Performative and Political Dimensions of Facebook Abstention. New Media \& Society 15(7): 1,041-1,057.

Rawls, John. 1996. Political Liberalism. New York: Columbia University Press.

Reestorff, Camilla. 2014. Mediatised affective activism: The activist imaginary and the topless body in the Femen Movement. Convergence 20(4): 478-495.

Rose, Nickolas. 1998. Governing the Soul. London: Free Association Books.

Ross, Andrew. 2003. No Collar: The Humane Workforce and Its Hidden Costs. New York: Basic Books.

Shachtman, Noah. 2013. In Silicon Valley Meditation is no Fad. It Could Make Your Career. Wired. Accessed November 14. http://www.wired.com/2013/06/meditation-mindfulnesssilicon-valley/

Schoenbeck, Sarita. 2014. Developing Healthy Habits with Social Media: Theorizing the Cycle of Overuse and Taking Breaks. Proceeds of SIGCHI, ACM Press.

Shirky, Clay. 2008. Here Comes Everybody: The Power of Organizing without Organizations. New York: Penguin Press.

Sutton, Theodora. 2014. "Recommended Daily Allowance: Digital Detox”. M.Sc. dissertation, University College of London, London.

White, Martha C. 2016. Here's How Much It Really Costs to Go To Burning Man. Time. Accessed September 19. http://time.com/money/4459656/how-much-burning-man-costs/

Woodstock, Louis. 2011. Performing Internet Resistance: Attempting to Opt Out of Online Participation. Paper presented at the Internet Research 12.0, Association of Internet Researchers. Seattle, Washington, October 8-11. 
Terranova, Tiziana. 2000. Free Labor: Producing Culture for the Digital Economy. Social Text 63 18(2): 33-58.

The Go Game. 2016. About. Accessed 2016. http://thegogame.com/team-building/about/ Turner, Fred. 2006. From Counterculture to Cyberculture: Stewart Brand, the Whole Earth Network, and the Rise of Digital Utopianism. Chicago: University of Chicago Press.

Turner, Fred. 2009. Burning Man at Google: A Cultural Infrastructure for New Social Media Production. Social Media and Society 11: 73-94.

Urry, John. 2002. Global Complexity. London: Wiley.

Winner, Langdon. 1980. “Do Artifacts Have Politics?” Daedalus 109(1): 121-136.

Zandbergen, Dorien. 2012. Fulfilling the Sacred Potential of Technology: New Edge Technophilia, Consumerism and Spirituality in Silicon Valley. In Things: Material Religion and the Topography of Divine Spaces, edited by Dick Houtman and Birgit Meyer, 356-379. New York: Fordham University Press.

\begin{abstract}
About the Author
Adam Fish is a cultural anthropologist, video producer, and senior lecturer in the Sociology Department at Lancaster University. He uses ethnographic and creative methods to investigate how media technology and political power interconnect. Using theories from political economy and new materialism, he examines digital industries and digital activists. His book Technoliberalism (Palgrave Macmillan, 2017) describes his research on the politics of internet video and the book After the Internet (Polity, 2017) recounts his work on the politics of hacktivism. He is presently working on a book about hacker subjectivity and the state, called Hackers States, and an experimental video using drones to map the undersea Internet cables and data centres in the North Atlantic. Before joining academia, he was a federal and tribal archaeologist for ten years working to preserve the cultural heritage of Native Americans of the Pacific Northwest.
\end{abstract}

